\author{
A.S. Rudenkov ${ }^{1}$, M.A. Yarmolenko ${ }^{1}$, A.A. Rogachev ${ }^{2}$, \\ A.P. Surzhikov ${ }^{3}$, A.P. Luchnikov ${ }^{4}$, O.A. Frolova ${ }^{4}$ \\ ${ }^{I}$ Francisk Skorina Gomel State University, Gomel, Belarus; \\ ${ }^{2}$ Belarusian State University of transport, Gomel, Belarus; \\ ${ }^{3}$ Tomsk Polytechnic University, School of Non-Destructive Testing, Tomsk, Russia; \\ ${ }^{4}$ MIREA - Russian Technological University, Russia \\ (*E-mail: fisika@mail.ru)
}

\title{
Phase composition and morphology of nanostructured coatings deposited by laser dispersion of a mixture of polyethylene with iron oxalate
}

\begin{abstract}
Peculiarities of forming of iron oxide coatings with reinforced carbon nanostructures from gas phase generated by laser dispersion of composite target were explored. Influence of technological modes of heat treatment on morphology and phase composition of nanostructured film layers was determined. It was found that on a substrate highly dispersed layers containing carbon nanostructures are formed. Using Raman spectroscopy it was shown that in oxide matrix carbon structures, which are mainly in the form of planar located nanotubes, appear. It was found that with a mass ratio of polyethylene and iron oxalate equal to 1:1, the distribution of the formed nanostructures in size is unimodal with a maximum near $20 \mathrm{~nm}$. At dispersing of polyethylene and iron oxalate mixture with mass ratio 1:2 in deposited layers nanotubes have the least defectiveness. Patterns of influence on morphology and coatings phase composition of relative component abundance in being dispersed by laser radiation composite target were determined. It was shown that with the growing of iron oxalate concentration in the target coating structural heterogeneity increases, subroughness and average size of separate nanostructures in the deposited condensate grow. The obtained polymer matrix nanocomposite films can be used in sensors.
\end{abstract}

Keywords: polyethylene, oxalate mixture, coating, nanostructures, morphology, phase composition, Raman spectroscopy.

\section{Introduction}

One of the promising ways to increase mechanical, thermophysical properties of thin coatings is to reinforce them with nanosized structures, in particular, carbon nanotubes, fullerenes [1-3]. Reinforcement of coatings with carbon nanostructures (nanocrystalline graphite, carbon nanotubes etc) due to their high mechanical properties will allow increasing strength and plasticity of such coatings with simultaneous preservation of high hardness. At the same time, the implementation of such technological technique, as a rule, involves complex, sequentially conducted operations and hence the development of methods for vacuum synthesis of such heterogeneous structures carried out in a single technological cycle with the possibility of controllincg the degree of reinforcement, morphology, and phase composition becomes relevant.

It is known that one of the effective methods of nanotubes synthesis is their formation from carbon gases at high enough temperature in the presence of catalysts, for which compounds, as a rule, oxides of transition metals are used [4]. It should be noted that layer deposition of metal oxide is of special interest and implementation of conditions, under which oxides being deposited on the surface as coatings catalyze processes of carbon nanotubes increase being formed in the volume of oxide have scientific and practical interest.

The study considers formation peculiarities of iron oxide coatings with reinforced carbon nanostructures from gas phase generated by laser dispersion of composite target and determines influence of technological modes of heat treatment on morphology and phase composition of nanostructured film layers.

\section{Samples and research methods}

Nanostructred coatings using iron oxide were obtained by laser dispersion of composite target based on polyethylene and iron oxalate, preheated to the temperature $330^{\circ} \mathrm{C}$. The target was prepared by polyethylene powder $(\mathrm{PP})$ and iron oxalate $\left(\mathrm{FeC}_{2} \mathrm{O}_{4} \cdot 2 \mathrm{H}_{2} \mathrm{O}\right)$ mixing with various mass ratio 1:1, 1:2, 1:3. The received powders mixture was placed into crucible on the heating panel. When the pressure in the vacuum chamber was $\sim 4 \cdot 10^{-3} \mathrm{~Pa}$ the power of the heating panel turned on providing the target heating up to $330^{\circ} \mathrm{C}$. Laser L-2137U+HG-5 was used as a source of laser radiation, which enables to carry out wavelength agility of laser radiation within the interval from infra-red $(1064 \mathrm{~nm})$ to ultraviolet range $(355,266 \mathrm{~nm})$. Frequency of 
impulse rate was $10 \mathrm{~Hz}$, the duration of pumping impulse in Q-switched mode was $6 \mathrm{~ns}$. The laser spot diameter made $7 \mathrm{~mm}$. Radiation with wavelength of $\lambda=532 \mathrm{~nm}$ was used in the study. Pulse energy corresponded to $380 \mathrm{~mJ}$.

The source of laser radiation switched on only after the formation of homogenous melt in the crucible. The impact of laser radiation with melt was accompanied by intensive gas phase generation. The crucible heating wasn't turned off within the whole period of laser dispersion. The substrate temperature was $350{ }^{\circ} \mathrm{C}$ that was considerably lower than the temperature of the synthesis of carbon nanostructures from the carbons on the surface of the catalyst which makes $500-700{ }^{\circ} \mathrm{C}[1-4]$.

\section{Experimental results and their discussion}

Patterns of influence on morphology and coatings phase composition of relative component abundance in being dispersed by laser radiation composite target were determined. It was shown that with the growing of iron oxalate concentration in the target coating structural heterogeneity increases, subroughness and average size of separate nanostructures in the deposited condensate grow (Fig. 1, Table 1).

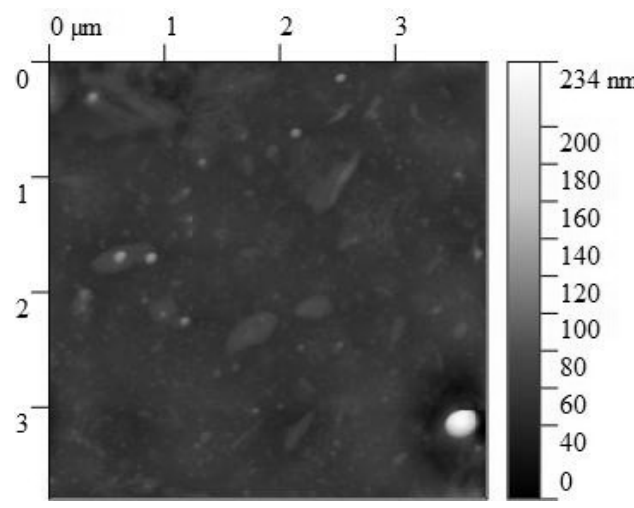

$\mathrm{PE}+\mathrm{Fe}(1: 1)$
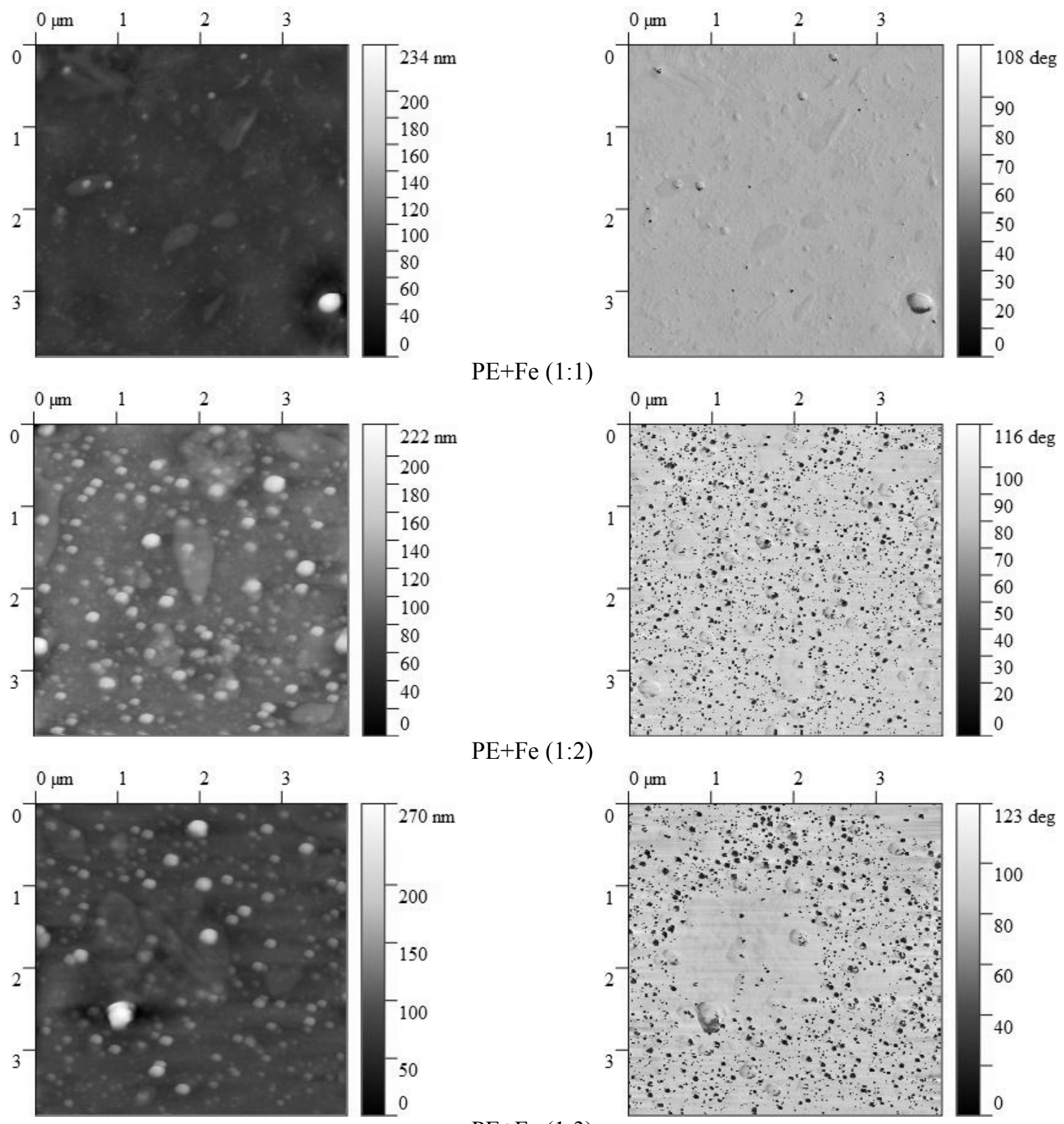

Topography

$\mathrm{PE}+\mathrm{Fe}(1: 3)$

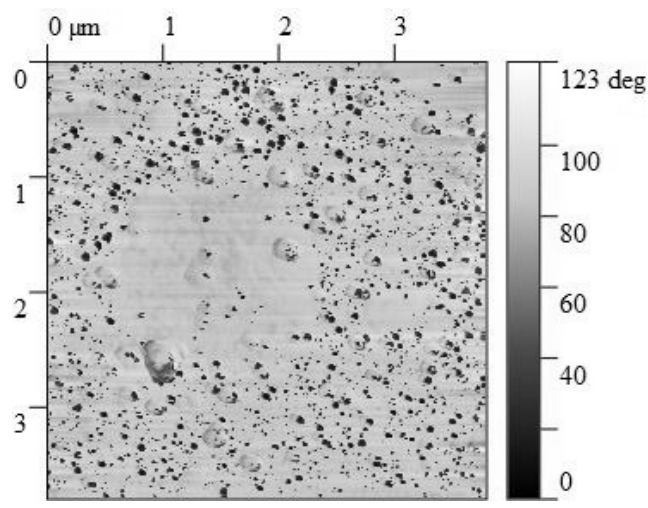

Phase contrast

Figure 1. AFM images of deposited metal carbon films of the condensate with mass ratio (1:1, 1:2 and 1:3) of the target components $(\mathrm{PE}+\mathrm{Fe})$ 
Influence of mass ratio of the target $(\mathrm{PE}+\mathrm{Fe})$ on morphological peculiarities of deposited metal-carbon condensate

\begin{tabular}{|c|c|c|c|c|c|}
\hline Coating & Mass ratio & Medium height, $\mathrm{nm}$ & $R_{\mathrm{ms}}, \mathrm{nm}$ & Grain density, pc. & $\begin{array}{c}\text { Average diameter } \\
\text { of grains, } \mathrm{nm}\end{array}$ \\
\hline \multirow{3}{*}{$\mathrm{PE}+\mathrm{Fe}$} & $1: 1$ & $59.3 / 139.4$ & $11.0 / 22.6$ & $246 / 94$ & $50 / 91$ \\
\cline { 2 - 6 } & $1: 2$ & $84.0 / 64.6$ & $14.9 / 15.3$ & $255 / 138$ & $70 / 112$ \\
\cline { 2 - 6 } & $1: 3$ & $98.5 / 39.2$ & $18.6 / 6.5$ & $244 / 85$ & $77 / 52$ \\
\hline
\end{tabular}

Note. Without thermal annealing/thermal annealing.

Particles on the surface contain intermediate compounds of molecule decomposition of iron oxalate and their size increase can be explained by their more intensive dissociation with phase formation of various compositions. Besides, it must be taken into consideration that laser dispersion is conducted in the preheated to $330^{\circ} \mathrm{C}$ mixture of polyethylene and iron oxalate. According to [5] iron oxalate hydrant loses crystallization water in the vacuum at $142{ }^{\circ} \mathrm{C}$. At further heating to $400-500^{\circ} \mathrm{C}$ due to laser treatment, decomposition products consist of iron oxide $\mathrm{Fe}_{3} \mathrm{O}_{4}$ or $\mathrm{FeO}$, containing pure iron. As on the figures of phase contrast (Fig. 1) structural heterogeneity is darker, they can be interpreted as objects with lower hardness consisting of iron mainly.

It was found that with a mass ratio of polyethylene and iron oxalate equal to $1: 1$ the distribution of the formed nanostructures $\mathrm{N}$ in size (radius $\mathrm{R}_{\mathrm{N}}$ ) is unimodal with a maximum near $20 \mathrm{~nm}$ (Fig. 2). With the further increase in the content of iron oxalate $(1: 2,1: 3)$ the radius distribution of the formed nanostructures shifts towards large particles and with high iron oxalate content in the target becomes unimodal, local maxima appear in the range from 30 to $50 \mathrm{~nm}$, indicating more intensive emission of nanophase iron.

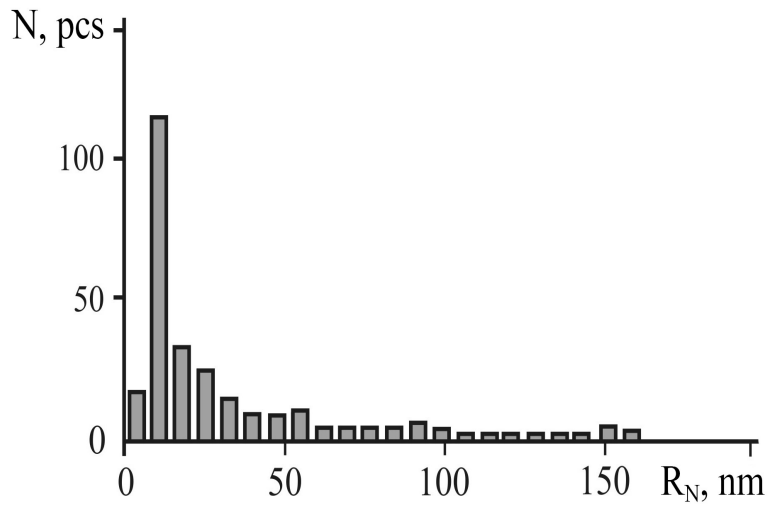

$\mathrm{PE}+\mathrm{Fe}(1: 1)$

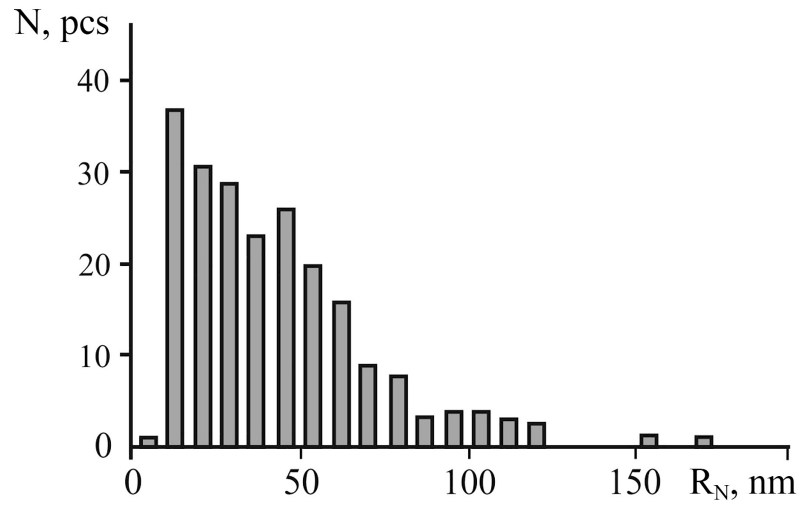

$\mathrm{PE}+\mathrm{Fe}(1: 2)$

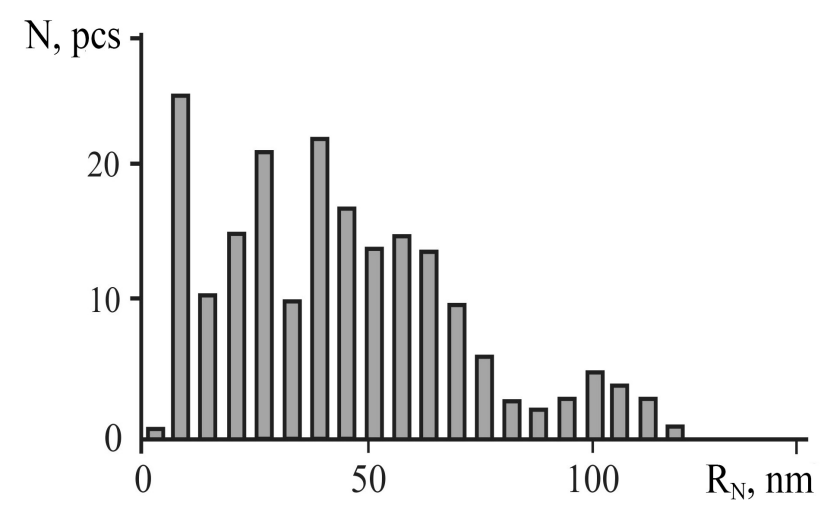

$\mathrm{PE}+\mathrm{Fe}(1: 3)$

Figure 2. Distribution histogram of the forming nanostructures $N$ in their radius size $\mathrm{R}_{\mathrm{N}}$ with mass ratio (1:1, 1:2 and 1:3) of the target components $(\mathrm{PE}+\mathrm{Fe})$ 
Heat treatment of coatings during an hour in air at a temperature of $500{ }^{\circ} \mathrm{C}$, in case of mass ratio polyethylene-iron oxalate $1: 1$ and 1:2, leads to the density reduction of structural formations and their size $\mathrm{R}_{\mathrm{N}}$ increase (Fig. 3, 4 and Table 1). The process is considerably stemmed from the occurrence of coalescence and partial oxidation of pure iron particles. At the same time in case of dispersion of the target with high content of iron oxalate (1:3) the distribution of the particles in size transforms from unimodal into exponential. Their size decrease is observed which is probably related with the intensive occurrence of iron oxidation. The conclusion is supported by significant (more than 3 times) decrease of particles density (Table 1).

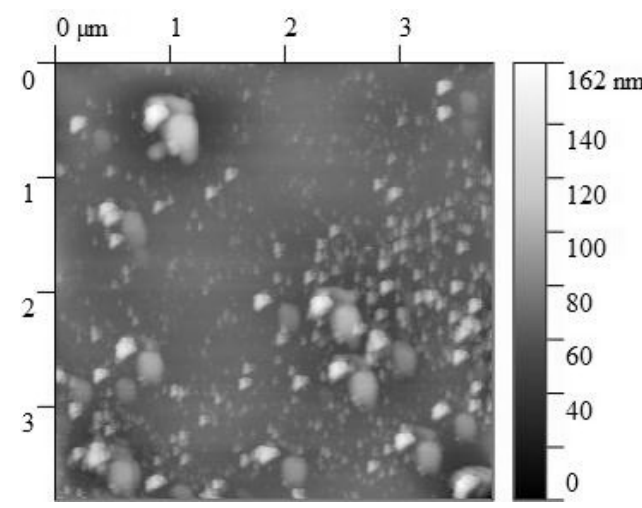

$\mathrm{PE}+\mathrm{Fe}(1: 1)$
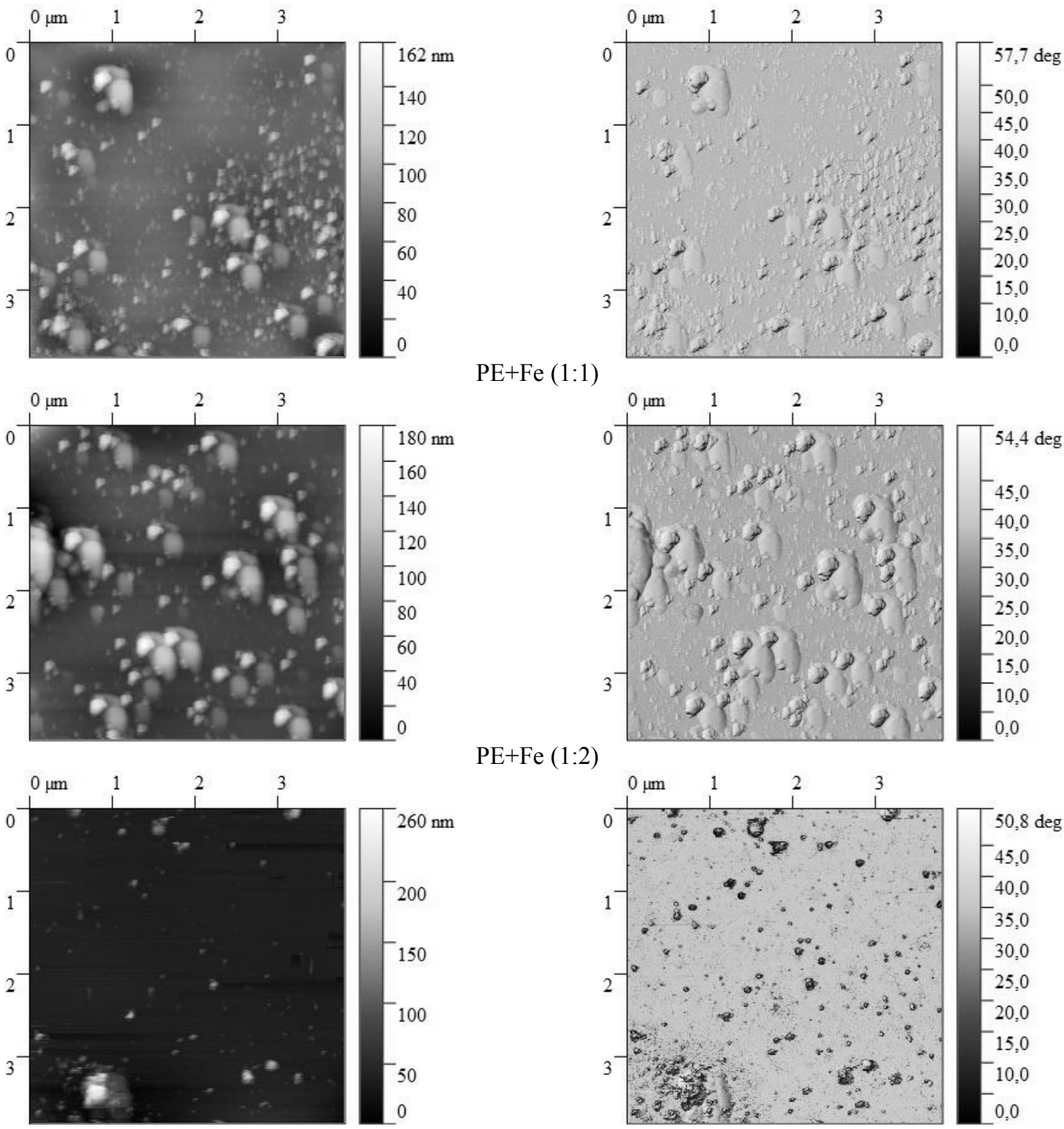

$\mathrm{PE}+\mathrm{Fe}(1: 2)$

Topography

$\mathrm{PE}+\mathrm{Fe}(1: 3)$

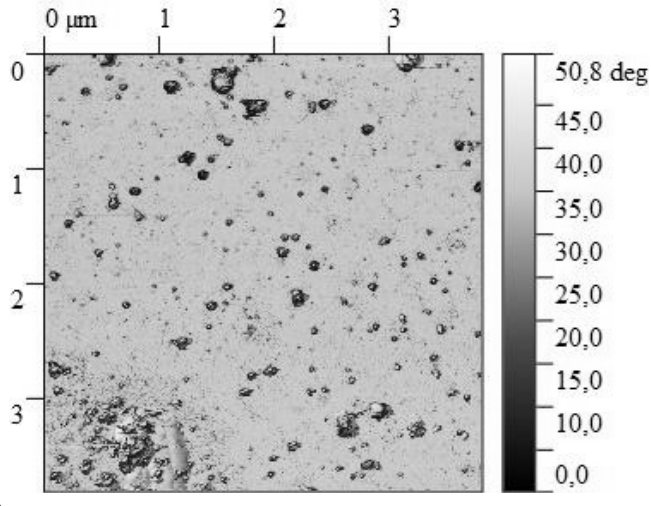

Phase contrast

Figure 3. AFM images of deposited metal carbon films of the condensate after the thermal annealing at a temperature of $500{ }^{\circ} \mathrm{C}$ with mass ratio $(1: 1,1: 2$ and 1:3) of the target components $(\mathrm{PE}+\mathrm{Fe})$

On Figure 5 Raman spectra of nanostructured layers deposited by laser dispersion of the target with various content are shown. According to [6-10] spectra of such form are typical for carbon nanomaterials. It is known that vibration band (G-peak) at $1575 \mathrm{~cm}^{-1}$ is determined by stretching vibration mode $\mathrm{E}_{2 \mathrm{~g}}$ of graphite lattice of infinite crystal [11]. The mode at $1355 \mathrm{~cm}^{-1}$ (D-peak) Raman spectrum corresponds to $\mathrm{A}_{1 \mathrm{~g}}$ mode, radial modes of hexagonal rings (often called «breathing» mode) [12]. D-peak occurs as a result of a binary resonant process [13] and appears if there are defects of structured carbon [14] and evidently marked bound- 
aries of nanocrystalline areas, it is typical for various carbon nanostructures (single-walled and multi-walled nanotubes, fullerenes, graphenes etc.) [15].

It should be mentioned that the band, determined by symmetric modes of $\mathrm{C}-\mathrm{H}$ bonds in $\mathrm{CH}_{2}$ and asymmetric ones in $\mathrm{CH}_{3}$ [7], is also registered in the interval between $2800-3000 \mathrm{~cm}^{-1}$. C-H bonds in the coating result from the dispersion of polyethylene and adsorption of volatile products on the substrate surface.

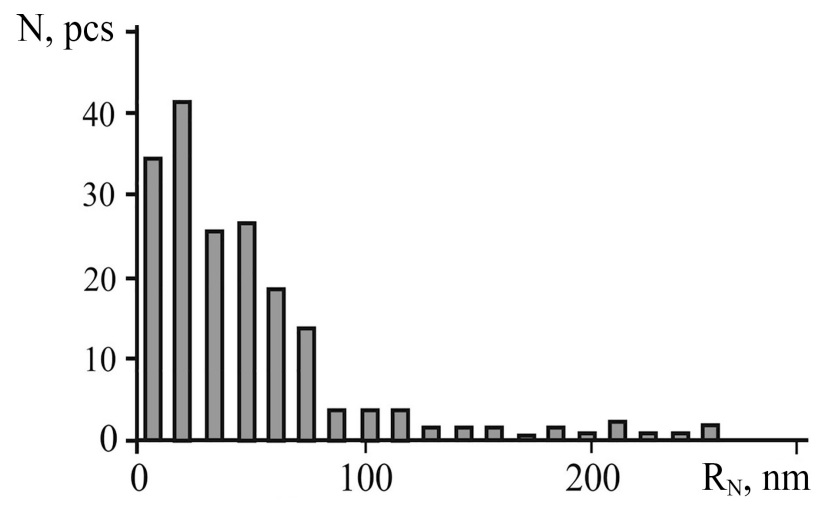

$\mathrm{PE}+\mathrm{Fe}(1: 1)$

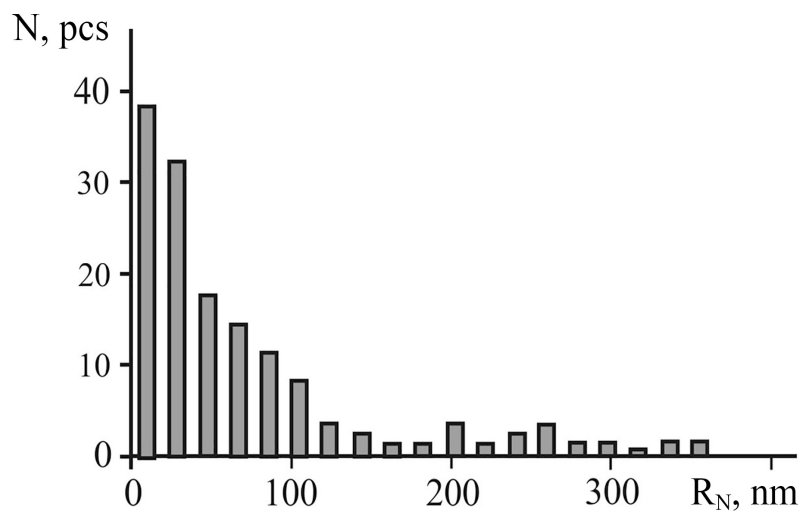

$\mathrm{PE}+\mathrm{Fe}(1: 2)$

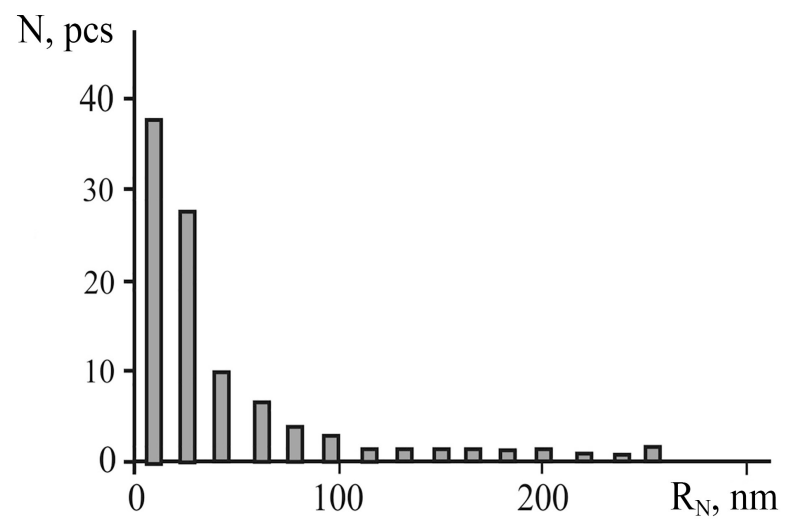

$\mathrm{PE}+\mathrm{Fe}(1: 3)$

Figure 4. Distribution histogram of the forming nanostructures $\mathrm{N}$ in their radius size $\mathrm{R}_{\mathrm{N}}$ after the thermal annealing at a temperature of $500{ }^{\circ} \mathrm{C}$ with mass ratio $(1: 1,1: 2$ and 1:3) of the target components $(\mathrm{PE}+\mathrm{Fe})$

The presented Raman spectra clearly indicate that resulting from laser dispersion of a mixture of polyethylene with iron oxalate in the volume of the layer, carbon nanostructures such as fullerenes, nanotubes and probably multi-walled nanotubes (MWNT) are formed. Except $E_{2 g}$ and $A_{1 g}$ the occurrence of radial modes near $200 \mathrm{~cm}^{-1}$ [16] and G'-peak in the range of 2450-2650 $\mathrm{cm}^{-1}$ [17] is characteristic of single-walled nanotubes. Spectra do not allow identifying them clearly as they have only $E_{2 g}$ and $A_{1 g}$ modes which are typical for carbon coatings and materials. Aiming at analysis of dispersion influence on the content of carbon formations, the obtained Raman spectra were arranged according to Gaussian elimination on D- $\left(\sim 1350 \mathrm{~cm}^{-1}\right)$ and G-peaks $\left(\sim 1580 \mathrm{~cm}^{-1}\right)$. Besides, base on requirements of error minimization, at decomposition extra D1peak near $1500 \mathrm{~cm}^{-1}$ (Fig. 5), associated with defective packaging and fullerenes and graphene clusters [8] was added.

The intensity ratio of $I_{G}$ and $I_{D}$, is usually used to determine defect rates of structures $[7,10]$. For example, if $I_{D}$ is higher than $I_{G}$, this points to the failure of long-range crystalline and disordered areas. Such effect can be observed not only in nanotubes with a large number of defects, but also can appear due to metal impurities in amorphous carbon particles, short carbon fiber and simply due to layers of amorphous carbon on external surfaces of nanotubes [7].

Among examined testing samples layers deposited by dispersion of polyethylene with iron oxalate mixture with mass ratio $1: 2$, are characterized by the minimum value of $I_{D} / I_{G}$ ratio (Table 2) which combined 
with the smallest width of D1-peak indicates minimum content of nanostructures defects. G-peak discomposition to $1600 \mathrm{~cm}^{-1}$ also demonstrates disorderliness of crystalline lattice of graphite [9]. Besides, indicated samples are characterized by great D-peak width value showing high content of nanoclusters of $\mathrm{sp}^{3}$-hybridized carbon [18].

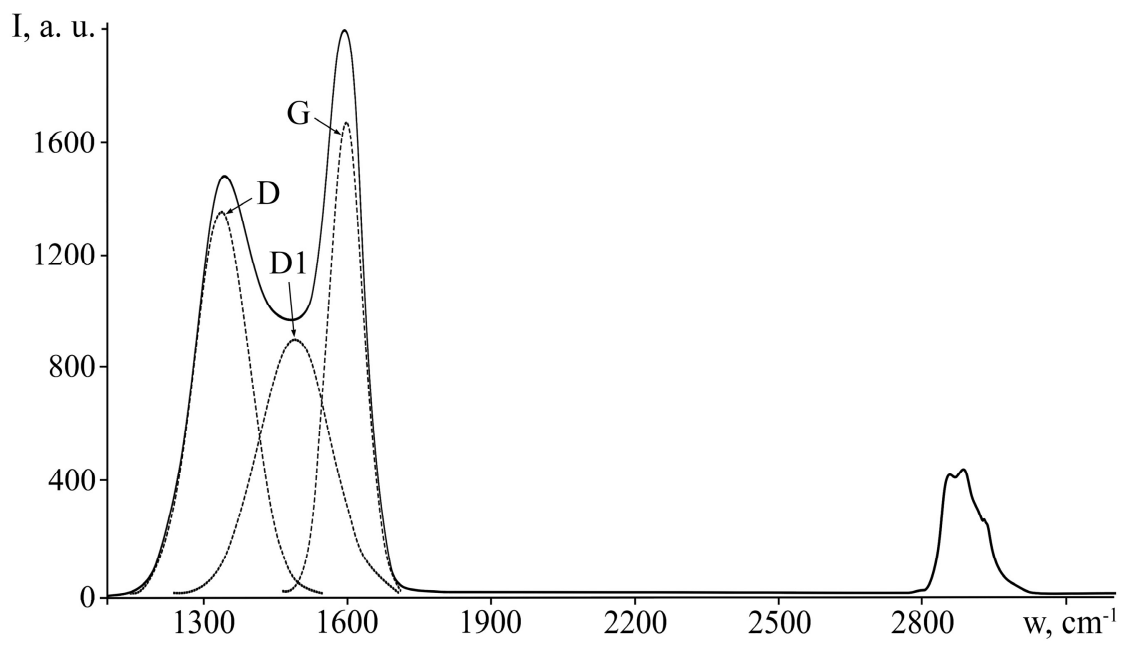

Figure 5. Typical Raman spectrum for nanostructured coatings deposited by laser dispersion of a mixture of polyethylene with iron oxalate

At the same time D1-peak shifting to $1520 \mathrm{~cm}^{-1}$ is typical for samples deposited by dispersion of polyethylene with iron oxalate mixture with mass ratio $1: 3$, which combined with $\mathrm{I}_{\mathrm{D}} / \mathrm{I}_{\mathrm{G}}$ increase, the decrease of the size of graphene clusters can be explained [8], since under [11] $\mathrm{I}_{\mathrm{D}} / \mathrm{I}_{\mathrm{G}}$ is in inverse proportion to the size of carbon clusters. Nanostructures (nanotubes, fullerenes or graphene fragment) in condensate deposited by laser dispersion of polyethylene with iron oxalate are indirectly confirmed by Raman spectrum of carbon coatings (Table 2) deposited by laser dispersion of graphite.

T a b l e 2

Phase composition of nanostructured coatings

\begin{tabular}{|c|c|c|c|c|c|c|c|}
\hline \multirow{2}{*}{$\begin{array}{c}\text { Mass ratio } \\
\text { PE+Fe }\end{array}$} & \multicolumn{2}{|c|}{ D-peak } & \multicolumn{2}{c|}{ D1-peak } & \multicolumn{2}{c|}{ G-peak } & \multirow{2}{*}{$\mathrm{I}_{\mathrm{D}} / \mathrm{I}_{\mathrm{G}}$} \\
\cline { 2 - 8 } & Position, $\mathrm{cm}^{-1}$ & Width, $\mathrm{cm}^{-1}$ & Position, $\mathrm{cm}^{-1}$ & Width, $\mathrm{cm}^{-1}$ & Position, $\mathrm{cm}^{-1}$ & Width, $\mathrm{cm}^{-1}$ & \\
\hline УП & 1430 & 245 & - & - & 1562 & 200 & 0,46 \\
\hline $1: 1$ & 1330 & 138 & 1479 & 222 & 1599 & 90 & 0,54 \\
\hline $1: 2$ & 1348 & 180 & 1480 & 105 & 1590 & 97 & 0,60 \\
\hline $1: 3$ & 1348 & 148 & 1520 & 149 & 1602 & 88 & 1,01 \\
\hline
\end{tabular}

Firstly, D-peak of carbon coatings is near $1430 \mathrm{~cm}^{1}$, and D-peak of nanostructured carbon layers is near $1350 \mathrm{~cm}^{-1}$. Such displacement is caused by structure disorder to a greater degree that is evident as carbon coatings are an amorphous carbon matrix [19]. Secondly, Raman spectra decomposition of carbon coatings excludes variants of peak arrangement near $1500 \mathrm{~cm}^{-1}$, related to defective packaging and graphene clusters.

After condensate heat treatment deposited by laser dispersion of polyethylene with iron oxalate due to the occurrence of processes of coalescence on Raman spectrum peaks appear near $220 \mathrm{~cm}^{-1}, 280 \mathrm{~cm}^{-1}$, $392 \mathrm{~cm}^{-1}, 601 \mathrm{~cm}^{-1}$, corresponding to $\alpha$-Fe and iron carbide [20], and also the peak near $650 \mathrm{~cm}^{-1}$, caused by $\mathrm{Fe}_{3} \mathrm{O}_{4}$ can be seen [21]. Peaks occurrence near $520 \mathrm{~cm}^{-1}$ and $960 \mathrm{~cm}^{-1}$, relating with polycrystalline silicon [22], is explained by lack of coating density. After heat treatment the peak near $2800-3000 \mathrm{~cm}^{-1}$, as well as D- and G- peaks disappear caused by destruction of $\mathrm{C}-\mathrm{N}$ bonds and carbon oxidation in the air.

\section{Conclusion}

It was shown that upon laser dispersion of a composite target based on polyethylene and iron oxalate, preheated to a temperature of $330^{\circ} \mathrm{C}$, coatings consisting of iron and its oxides and reinforced with carbon nanostructures are deposited. It was found that with a mass ratio of polyethylene and iron oxalate equal to $1: 1$, the distribution of the formed nanostructures in size (radius) is unimodal with a maximum near $20 \mathrm{~nm}$. 
With a further increase in the content of iron oxalate $(1: 2,1: 3)$, the radius distribution of the formed nanostructures becomes multimodal, local maxima appear in the range from 30 to $50 \mathrm{~nm}$. During heat treatment of coatings in air at a temperature of $500{ }^{\circ} \mathrm{C}$, the density of structural formations decreases and their size increases which is explained by the occurrence of processes of coalescence and partial oxidation of pure iron particles. Using Raman spectroscopy it was found that carbon nanostructures formed in the coating volume are highly defective and the phase composition depends on the content of polyethylene in the target. The obtained polymer matrix nanocomposite films can be used in sensors [23, 24].

The study was supported by the Ministry of Education of the Republic of Belarus (task 2.64), as well as by the Ministry of Science and Higher Education of Russian Federation (project No. 0706-2020-0022).

\section{References}

1 Booker R. Nanotechnology for dummies / R. Booker. - Wiley Publishing Inc, 2005. — 366 c. ISBN 978-0-7645-8368-1

2 Boul P.J. Reversible sidewall functionalization of buckytubes / P.J. Boul // Chemical Physics Letters. — 1999. — Vol. 310. - P. 367-372. DOI: 10.1016/S0009-2614(99)00713-7

3 Белянин А.Ф. Наноструктурированные углеродные материалы в эмиссионной электронике / А.Ф. Белянин, В.В. Борисов, А.С. Багдасарян // Рос. технол. журн. - 2017. — Т. 5, № 5. - С. 22-40. https://doi.org/10.32362/2500-316X2017-5-3-22-40

4 Колокольцев С.Н. Углеродные материалы. Свойства, технологии, применения / С.Н. Колокольцев. - Долгопрудный: ИД «Интеллект», 2012. - 296 с.

5 Чуриков А.В. Об использовании оксалата железа $\mathrm{FeC}_{2} \mathrm{O}_{4} \cdot 2 \mathrm{H}_{2} \mathrm{O}$ для синтеза электродного материала $\mathrm{LiFePO}_{4} /$ А.В. Чуриков, И.А. Леенсон // Электрохимическая энергетика. - 2012. - Т. 11. - С. 14-20.

6 Zhang H.B. Raman spectra of MWCNTs and MWCNT-based $\mathrm{H}_{2}$-adsorbing system / H.B. Zhang // Carbon. - 2002. Vol. 40. - P. 2429-2436. DOI:10.1016/S0008-6223(02)00148-3

7 Song J.I. Formation of carbon nanotubes catalyzed by rare earth oxides / J.I. Song // New Carbon Materials. — 2013. Vol. 28. - P. 191-198. DOI:10.1016/S1872-5805(13)60076-1

8 Chernyak S.A. N-doping and oxidation of carbon nanotubes and jellyfish-like grapheme nanoflakes through the prism of Raman spectroscopy / S.A. Chernyak // Applied Surface Science. - 2019. - Vol. 488. - P. 51-60. DOI: 10.1016/j.apsusc.2019.05.243

9 Haque A. Synthesis of diamond nanostructures from carbon nanotube and formation of diamond-CNT hybrid structures / A. Haque // Carbon. - 2019. — Vol. 150. — P. 388-395. DOI: 10.1016/j.carbon.2019.05.027

10 Hur J. Raman intensity and vibrational modes of armchair CNTs / J. Hur // Chemical Physics Letters. — 2017. — Vol. 679. - P. 45-51. DOI:10.1016/j.cplett.2017.04.078

11 Tuinstra F. Raman spectrum of graphite / F. Tuinstra, J.L. Koenig // Journal of Chemical Physics. — 1970. — Vol. 53. — P. 1126-1130. DOI: $10.1063 / 1.1674108$

12 Kusiak-Nejman E. Hybrid carbon- $\mathrm{TiO}_{2}$ spheres: investigation of structure, morphology and spectroscopic studies / E. Kusiak-Nejman // Applied Surface Science. — 2018. — Vol. 469. — P. 684-690. DOI: 10.1016/j.apsusc.2018.11.093

13 Thomsen C. Double resonant Raman scattering in graphite / C. Thomsen, S. Reich // Physical Review Letters. - 2000. Vol. 85. - P. 5214-5217. DOI: 10.1103/PhysRevLett.85.5214

14 Wang Y. Raman spectroscopy of carbon materials: structural basis of observed spectra / Y. Wang, D.C. Alsmeyer, R.L. McCreery // Chemistry of Materials. — 1990. - Vol. 2. - P. 557-563. DOI: 10.1021/cm00011a018

15 Данишевский А.М. Комбинационное рассеяние света в нанопористом углероде, получаемом из карбидов кремния и титана / А.М. Данишевский, Э.А. Сморгонская, С.К. Гордеев, А.В. Гречинская // Физика твердого тела. — 2001. — Т. 43. C. $132-149$.

16 Dresselhaus M.S. Raman spectroscopy of carbon nanotubes / M.S. Dresselhaus // Physics Reports. — 2005. — Vol. 409. — P. 47-99. DOI: 10.1016/j.physrep.2004.10.006

17 Aqel A. Carbon nanotubes, science and technology part (I) structure, synthesis and characterization / A. Aqel // Arabian Journal of Chemistry. — 2012. — Vol. 5. - P. 1-23. DOI: 10.1016/j.arabjc.2010.08.022

18 Prawer S. Raman spectroscopy of diamond and doped diamond / S. Prawer, R.J. Nemanich // Philosophical Transactions of the Royal Society A: Mathematical, Physical and Engineering Sciences. - 2004. - Vol. 362. - P. 2537-2565. DOI: 10.1098/rsta.2004.1451

19 Piliptsou D.G. XPS study of the structure of nitrogen doped a-C film / D.G. Piliptsou, A.S. Rudenkov, A.V. Rogachev, Xiaohong Jiang, P.A. Lychnikov, V.A. Emel'yanov // IOP Conference Series: Materials Science and Engineering. — 2017. Vol. 168. - P. 012103 (P.1). DOI: 10.1088/1757-899X/168/1/012103.

20 Подгорный В.И. Получение образцов карбидов в плазме дугового разряда / В.И. Подгорный, Б.З. Белашев, Р.Н. Осауленко, А.Н. Терновой // Журн. техн. физ. - 2013. - Т. 83. - С. 77-81.

21 Iconaru S.L. Magnetite $\left(\mathrm{Fe}_{3} \mathrm{O}_{4}\right)$ nanoparticles as adsorbents for $\mathrm{As}$ and $\mathrm{Cu}$ removal / S.L. Iconaru, R. Guégan, C.L. Popa, M. Motelica-Heino, C.S. Ciobanu, D. Predoi // Applied Clay Science. - 2016. - Vol. 134. — P. 128-135. DOI: 10.1016/j.clay.2016.08.019

22 Mercaldo L.V. First and second-order Raman scattering in Si nanostructures within silicon nitride / L.V. Mercaldo // Applied Physics Letters. — 2010. — Vol. 97. — P. 153112-1-153112-3. DOI: 10.1063/1.3501133 
23 Wang S. Structure and properties of polyaniline nanocomposite coatings containing gold nanoparticles formed by low-energy electron beam deposition / S. Wang, A.A. Rogachev, M.A. Yarmolenko, A.V. Rogachev, Xiaohong Jiang, M.S. Gaur, P.A. Luchnikov, O.V. Galtseva, S.A. Chizhik // Applied Surface Science. - 2018. - Vol. 428. - P. 1070-1078. DOI: 10.1016/j.apsusc.2017.09.225

24 Sakenova R.E. The study of multilayer coatings based on MoN(MoZr)ZrN and (TiMo)N/(TiMo),(CrZr)N/(CrZr) obtained by the method of vacuum-arc deposition / R.E. Sakenova, N.K. Erdybaeva, A.D. Pogrebnjak, M.K. Kylyshkanov // Bulletin of the Karaganda University. Physics series. — 2019. — No. 2(94). — P. 14-21. DOI: 10.31489/2019Ph2/14-21

\author{
А.С. Руденков, М.А. Ярмоленко, А.А. Рогачев, \\ А.П. Суржиков, А.П. Лучников, О.А. Фролова
}

\title{
Полиэтиленнің темір оксалатымен қоспасын лазерлік диспергирлеу арқылы тұндырылатын наноқұрылымды жабындардың фазалық құрамы мен морфологиясы
}

\begin{abstract}
Композиттік нысанның лазерлік дисперсиясы нәтижесінде пайда болатын газ фазасынан күшейтілген көміртекті наноқұрылымдары бар темір оксиді жабындарының қалыптасу ерекшеліктері зерттелген. Термиялық өңдеудің технологиялық режимдерінің наноқұрылымды пленка қабаттарының морфологиясы мен фазалық құрамына әсері нақтыланған. Төсеніште көміртегі наноқұрылымдары бар жоғары дисперсті қабаттар пайда болатындығы дәлелденген. Раман спектроскопиясы әдісімен оксид матрицасында көміртекті құрылымдар пайда болатындығы көрсетілді, олар негізінен жалпақ орналасқан нанотүтікшелер түрінде ұсынылған. Полиэтилен мен темір оксалатының 1: 1 массалық қатынасында қалыптасқан наноқұрылымдардың мөлшері бойынша таралуы шамамен 20 нм болатын унимодальды екендігі анықталды. 1: 2 массалық қатынасы бар полиэтилен мен темір оксалатының қоспасын дисперсиялаған кезде, нанотүтікшелер балқытылған қабаттарда ең аз ақауларға ие болады. Лазерлік сәулеленудің композициялық нысанын дисперсиялау кезінде компоненттердің салыстырмалы құрамы жабындардың морфологиясы мен фазалық құрамына әсер ету заңдылықтары анықталған. Мақсатты жабындағы темір оксалатының концентрациясының жоғарылауымен құрылымдық гетерогенділік жоғарылайды, ішкі кедір-бұдыр және босатылған конденсаттағы жеке наноқұрылымдардың орташа мөлшері артады. Алынған полимерлі матрицасы бар нанокомпозитті пленкаларды сенсорларда қолдануға болады.
\end{abstract}

Кілт сөздер: полиэтилен, темір оксалат, жабын, наноқұрылымдар, морфология, фазалық құрам, раман спектроскопиясы.

\section{А.С. Руденков, М.А. Ярмоленко, А.А. Рогачев, А.П. Суржиков, А.П. Лучников, О.А. Фролова \\ Фазовый состав и морфология наноструктурированных покрытий, осаждаемых лазерным диспергированием смеси полиэтилена с оксалатом железа}

\begin{abstract}
Исследованы особенности формирования покрытий оксида железа с армированными углеродными наноструктурами из газовой фазы, генерируемой лазерным диспергированием композитной мишени. Определено влияние технологических режимов термообработки на морфологию и фазовый состав наноструктурированных пленочных слоев. Обнаружено, что на подложке формируются высокодисперсные слои, содержащие углеродные наноструктуры. Методом рамановской спектроскопии было показано, что в оксидной матрице возникают углеродные структуры, которые в основном представлены в виде плоскорасположенных нанотрубок. Установлено, что при массовом соотношении полиэтилена и оксалата железа 1: 1 распределение сформированных наноструктур по размерам является унимодальным с максимумом около 20 нм. При диспергировании смеси полиэтилена и оксалата железа с массовым соотношением 1: 2 в наплавленных слоях нанотрубки имеют наименьшую дефектность. Определены закономерности влияния на морфологию и фазовый состав покрытий относительного содержания компонентов при диспергировании композитной мишени лазерного излучения. Показано, что с увеличением концентрации оксалата железа в целевом покрытии повышаются структурная неоднородность, внутренняя шероховатость и средний размер отдельных наноструктур в выпавшем конденсате. Полученные нанокомпозитные пленки с полимерной матрицей могут быть использованы в сенcopax.
\end{abstract}

Ключевые слова: полиэтилен, оксалат железа, покрытие, наноструктуры, морфология, фазовый состав, КР-спектроскопия. 


\section{References}

1 Booker, R. (2005). Nanotechnology for dummies. New York: Wiley Publishing Inc.

2 Boul, P.J. (1999). Reversible sidewall functionalization of buckytubes. Chemical Physics Letters, 310, 367-372, DOI: 10.1016/S0009-2614(99)00713-7.

3 Belyanin, A.F., Borisov, V.V., \& Bagdasaryan, A.S. (2017). Nanostrukturirovannye uhlerodnye materialy v emissionnoi elektronike [Nanostructured carbon materials in emission electronics]. Rossiiskii tekhnolohicheskii zhurnal — Russian Technological Journal, 5(3), 22-40 [in Russian].

4 Kolokol'cev, S.N. (2012). Uhlerodnye materialy. Svoistva, tekhnolohii, primeneniia [Carbon materials. Properties, technologies, applications]. Dolgoprudnyi: ID «Intellekt» [in Russian].

5 Churikov, A.V., \& Leenson, A.V. (2012). Ob ispolzovanii oksalata zheleza $\mathrm{FeC}_{2} \mathrm{O}_{4} \cdot 2 \mathrm{H}_{2} \mathrm{O}$ dlia sinteza elektrodnoho materiala $\mathrm{LiFePO}_{4}\left[\mathrm{On}\right.$ the use of iron oxalate $\mathrm{FeC}_{2} \mathrm{O}_{4} \cdot 2 \mathrm{H}_{3} \mathrm{O}$ for synthesis of electrode material $\left.\mathrm{LiFePO}_{4}\right]$. Elektrokhimicheskaia enerhetika Electrochemical engineering, 11, 14-20 [in Russian].

6 Zhang, H.B. (2002). Raman spectra of MWCNTs and MWCNT-based $\mathrm{H}_{2}$-adsorbing system. Carbon, 40, 2429-2436, DOI: 10.1016/S0008-6223(02)00148-3.

7 Song, J.I. (2013). Formation of carbon nanotubes catalyzed by rare earth oxides. New Carbon Materials, 28, 191-198, DOI: $10.1016 /$ S1872-5805(13)60076-1.

8 Chernyak, S.A. (2019). N-doping and oxidation of carbon nanotubes and jellyfish-like grapheme nanoflakes through the prism of Raman spectroscopy. Applied Surface Science, 488, 51-60, DOI: 10.1016/j.apsusc.2019.05.243.

9 Haque, A. (2019). Synthesis of diamond nanostructures from carbon nanotube and formation of diamond-CNT hybrid structure. Carbon, 150, 388-395, DOI: 10.1016/j.carbon.2019.05.027

10 Hur, J. (2017). Raman intensity and vibrational modes of armchair CNTs. Chemical Physics Letters, 679, 45-51. DOI: 10.1016/j.cplett.2017.04.078.

11 Tuinstra, F. (1970). Raman spectrum of graphite. Journal of Chemical Physics, 53, 1126-1130, DOI: 10.1063/1.1674108.

12 Kusiak-Nejman, E. (2018). Hybrid carbon- $\mathrm{TiO}_{2}$ spheres: investigation of structure, morphology and spectroscopic studies. Applied Surface Science, 469, 684-690, DOI: 10.1016/j.apsusc.2018.11.093.

13 Thomsen, C. (2000). Double resonant Raman scattering in graphite. Physical Review Letters, 85, 5214-5217, DOI: 10.1103/PhysRevLett.85.5214.

14 Wang, Y. (1990). Raman spectroscopy of carbon materials: structural basis of observed spectra. Chemistry of Materials, 2 , 557-563. DOI: $10.1021 / \mathrm{cm} 00011 \mathrm{a} 018$

15 Danishevskii, A.M., Smorgonskaya, E.A., Gordeev, S.K., \& Grechinskaya, A.V. (2001). Kombinatsionnoe rasseianie sveta v nanoporistom uhlerode, poluchaemom iz karbidov kremniia i titana [Raman scattering in nanoporous carbon, obtaining from silicon and titanium carbide]. Fizika tverdoho tela - Solid state physics, 43, 132-149 [in Russian].

16 Dresselhaus, M.S. (2005). Raman spectroscopy of carbon nanotubes. Physics Reports, 409, 47-99. DOI:10.1016/j.physrep.2004.10.006.

17 Aqel, A. (2012). Carbon nanotubes, science and technology part (I) structure, synthesis and characterization. Arabian Journal of Chemistry, 5, 1-23, DOI: 10.1016/j.arabjc.2010.08.022.

18 Prawer, S. (2004). Raman spectroscopy of diamond and doped diamond. Philosophical Transactions of the Royal Society A: Mathematical, Physical and Engineering Sciences, 362, 2537-2565, DOI: 10.1098/rsta.2004.1451.

19 Piliptsou, D.G. (2017). XPS study of the structure of nitrogen doped a-C film. IOP Conference Series: Materials Science and Engineering, 168, 012103, DOI: 10.1088/1757-899X/168/1/012103.

20 Podgorny, V.I. (2013). Poluchenie obraztsov karbidov v plazme duhovoho razriada [Obtaining of carbide samples in arc discharge plasma]. Zhurnal tekhnicheskoi fiziki - The Journal of Technical Physics, 83, 77-81 [in Russian].

21 Iconaru, S.L. (2016). Magnetite $\left(\mathrm{Fe}_{3} \mathrm{O}_{4}\right)$ nanoparticles as adsorbents for As and $\mathrm{Cu}$ removal. Applied Clay Science, 134, 128 135. DOI: 10.1016/j.clay.2016.08.019.

22 Mercaldo, L.V. (2010). First and second-order Raman scattering in Si nanostructures within silicon nitride. Applied Physics Letters, 97, 153112-1-153112-3, DOI: 10.1063/1.3501133.

23 Wang, S. (2018). Structure and properties of polyaniline nanocomposite coatings containing gold nanoparticles formed by low-energy electron beam deposition. Applied Surface Science, 428, 1070-1078. DOI: 10.1016/j.apsusc.2017.09.225.

24 Sakenova, R.E., Erdybaeva, N.K., Pogrebnjak, A.D., \& Kylyshkanov, M.K. (2019). The study of multilayer coatings based on MoN(MoZr)ZrN and (TiMo)N/(TiMo), (CrZr)N/(CrZr) obtained by the method of vacuum-arc deposition. Bulletin of the Karaganda University. Physics series, 2(94), 14-21, DOI: 10.31489/2019Ph2/14-21. 